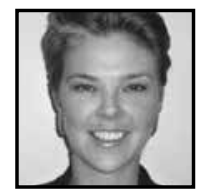

\title{
Learning From the Past to Inform Our Present: A Survey of the Evolution of Childhood and the Kindergarten
}

\author{
Lauren McCann, Concordia University
}

\section{ABSTRACT}

To understand the kindergarten of today, it is important to comprehend early childhood education of the past. This article surveys the evolution of childhood and of the kindergarten from past to present. The early schools of Oberlin, Pestalozzi, and Froebel are explored and focus is later placed on the past and the present Canadian/Quebec kindergarten system. Personal narratives from the classroom mark the conclusion of each section. These reflections encompass the overall emphasis of each segment by providing a look into the daily life of my teaching, hoping to bridge theory and practice.

\section{The Evolution of Childhood and Kindergarten}

\footnotetext{
ow did the kindergarten become the stepping-stone to school culture and
what role does Quebec have in this history? This article outlines the histories
of childhood, kindergarten, and kindergarten in Quebec.
}

\section{A Short History of Childhood}

The notion of childhood is a fairly modern concept. Prior to the 16th century, children, as we now would consider them, were thought to be small adults. In his famed text, Centuries of Childhood, historian Philippe Airès (1962), outlines the evolution of childhood and family life. During the 13th century, artists included images of children into their paintings. Children were depicted with distorted bodies resembling those of developed adults only in smaller form. Although children were represented during the 
13th century and the notions of childhood developed throughout the 14th and 15th century, it was not until the late 16th and early 17th century that the concept of childhood became more apparent. As described by Airès, literature of the time is riddled with language created specifically for children. Words such as toutou and bonbon were terms of endearment, however the concepts of childhood from the 17th century are far removed from those of today's society. Children of that time were exposed to adult life and all of its cruelties. Through researching the detailed diary of Henri IV's physician, Heroard, Airès discovered that Louis the XIII was known to have had sexual experiences at the whim of his elders before the age of three, and at fourteen years he was forced to bed his newly appointed wife. Heroard's journal outlined the many details of young Louis' life, many of which would today be considered shocking.

Historian J.H. Plumb (1971) adds to these thoughts with reference to popular art of the 16th century:

There was no separate world of childhood. Children shared the same games with adults, the same toys, the same fairy stories. They lived their lives together, never apart. The coarse village festivals depicted by Breughel, showing men and woman besotted with drink, groping for each other with unbridled lust, have children eating and drinking with the adults. Even in the sober pictures of wedding feasts and dances, the children are enjoying themselves along-side their elders, doing the same things. (p. 7)

Airès (1962) writes of the shift from this barbaric view of infancy to the image of cherubs later associated with the child. This change was brought on by the reformed ideas of influential pedagogues from both the Protestant and Roman Catholic churches that stood against such cruelties. They commissioned censored editions of timely classics, such as Comedies of Terence or the conversations of Erasmus, Mosellanus, and Vivès for their younger pupils. This resulted in ideas of protecting the child from the adult world, thus ensuring their innocence. The notion of the child as simplistic and naïve was echoed by the likes of Rousseau. His radical ideas found in Émile (1762/1892) fought to change the notion of childhood at the time. Rousseau opens this novel stating, "Everything is good as it comes from the hands of the Author of Nature; but everything degenerates in the hands of man" (p. 1). Rousseau valued play, the freedom of being a child and the possibilities of children learning by doing, not by pure memorization. These concepts of childhood connect to beliefs today. According to Airès, during the late 17th century, parents, like many today, held anxieties concerning the education of their children and their future. The child was now to stay pure and learn proper etiquette. 
Neil Postman (1981), in The Day Our Children Disappear:Predictions of a Media Ecologist, reflects on what he views as the turning point in history when childhood, as we know it, came to be. The turning point was the invention of the printing press. According to Postman, during the Dark and Middle ages, daily life was conducted through oral communication and so to partake in everyday activity, all a child needed was the ability to speak. Reading was not necessary and only the elite and the clergy possessed this skill. Gutenberg's invention of the printing press created two distinct groups of individuals: those who knew how to read and those who did not. Society soon became literature based. The need for reading became apparent and children were isolated from the rest of the community as non-literates. In order to partake in this newly created world of mass printing, children needed the skill of reading, thereby requiring tutelage from a school. According to Postman (1981), "Going to school was the essential event in creating childhood" (p. 384) and the need of reading "made childhood a necessity" (p. 36).

\section{History of the First Schools For Young Learners}

According to Harry Morgan (2011), distinguished author and observer of early childhood education, the first school in the Western world for children under the age of six opened in 1767 to serve the working class, coal-mining families of the French countryside. Its founder was Johann Friedrich Oberlin, who believed in free education for less fortunate children whose parents could not afford to supplement their child's educational needs. In Early Childhood Education: History, Theory, and Practice, Morgan describes Oberlin's schools as places where teachers "encourage[ed] language interaction and storytelling as starting points for art and music, along with learner-initiated project construction activities." (p. 11). These school were nicknamed "knitting schools" due to the simultaneous knitting by the educators while they engaged in conversation with their pupils. Conversation played a great role for Oberlin, who wished for his pupils to learn proper French, rather than their spoken dialects, in order to avoid job discrimination in the big cities. Oberlin created a child-centered environment where children were encouraged to learn at their own pace, and partake in physical activities while sharing in artistic ventures such as knitting, drawing, and creating herbariums. Many of these curricula concepts continue to be seen in today's early educational institutions.

Swiss educational reformer Johann Heinrich Pestalozzi is another prominent figure in the history of early childhood education. According to Norman Brosterman (1997) in his text Inventing Kindergarten, Pestalozzi, like Oberlin, educated students under the age of six. He, too, began his teachings with the less fortunate who were working in farmhouses and living in orphanages. In 1800, he established his first school for the poor in his own barn. Pestalozzi was a true pioneer in the field of early education 
as his philosophies of education favored active hands-on-learning and observation. Pestalozzi (1894) believed that through observation of social interactions, the child creates his/her own interpretation, thus serving as a model for his/her personal behavior.

In her text entitled Pestalozzi, Kate Silber (1973) writes of the many aspects of Pestalozzi's work that differed from other educational institutes of the time. Like many students of the 1800s, Pestalozzi's first pupils were simply learning by repetition. This method was changed, for Pestalozzi rejected the notion of rote memorization. He ensured his pupils understood their lessons before reciting anything. Pestalozzi thought that children should be taught only what is developmentally appropriate. In this respect, students should never be deprived of learning anything that they are capable of learning, but they should not be troubled by teachings that are beyond their understanding. Pestalozzi's philosophies on education were translated and compiled to create The Education of Man: Aphorisms with an introduction by William H. Kilpatrick (1951). Pestalozzi believed in the education of the whole child where love, joy, and reflection were present. He stated that, "life itself is the true basis of teaching and education" (p. 36). One of Pestalozzi's students would go on to influence school structure around the world. This famed student was none other than Friedrich Froebel, the founder of the kindergarten.

Froebel followed the teaching of Pestalozzi, yet created his own theories attached to Idealism and the philosophies of the American Transcendentalists of the time. Michael Steven Shapiro (1983), in Child's Garden: The Kindergarten Movement From Froebel to Dewey, simplifies Froebel's writings and summarizes Froebelian theories as such:

At the center of Froebel's education system lay the idea that mankind was the embodiment of God's reason. Froebel believed that the material world was only the outward expression of the inner divinity of all things...childhood held a special meaning, for it was a relatively uncorrupted embodiment of God's reason. (p. 20)

According to Froebel (1861/1909), children were good natured and pure. Their growth, with regards to developing personal connections between their inner and outer world, needed to be cultivated. It was in Froebel's kindergartens that this growing and nurturing took place. The word kindergarten echoes this concept as the German word "kinder" translates as children and the word "garten" as garden. The kindergarten is therefore the garden of children.

Norman Brosterman (1997), author of Inventing Kindergarten, relates how Froebel's theories went against the traditional teacher-directed student-response educational theories in Germany at the time. These theories were based on the omnipresent 
religious instruction of the Lutheran church. In order for the child to connect to his or her inner and outer world, self-activity, or what we refer to today as a child-centered curriculum, needed to be present:

Learning originated in the child itself, and expression became self-expression instead of recitation. The role of the teacher was thus transformed from lecturer to guide, as she now directed the child's natural movement towards play with one another and with freely expansive, but carefully defined gifts. (p. 33)

In his kindergarten, Froebel (1861/1909) used "gifts" and the "occupations" as teaching tools. There are a combined total of 20 gifts such as spheres, cubes, paper rings, blocks, and so forth-objects which stay in their true forms. The "occupations" (e.g., clay, sand, cardboard, mud) could be manipulated. The purpose of these "gifts" and "occupations" was to teach respect and gratitude of natural harmony, while awakening the child's senses to construct, observe, express, and reflect. Froebel's "gifts" and "occupations" assisted his views of making education "possible for man to feel and spontaneously to develop, to educate himself...as a whole human on earth... and in the harmony and union with the whole life..." (p. 9). Although these objects are not the focus in today's kindergarten, according to Gerald Gutek (1972), author of A History of the Western Educational Experience, Froebel's work did have effect as it "contributed to the liberalization of, and the legitimizing of, the role of play and activities in early childhood education" (p. 231).

In Early Childhood Education; History, Theory and Practice, Morgan (2011) writes of Margarethe Schurz, a student of Froebel's, who opened the first U.S. kindergarten in Wisconsin. However, Elizabeth Peabody is known for founding English Kindergarten in Boston, Massachusetts in 1860. According to Morgan, as a young woman, Peabody taught women in her mother's school and was introduced to Froebel's teaching from Schurz. She furthered her understandings of the kindergarten movement by traveling to Europe to study with Froebel himself.

\section{History of the Kindergarten in Canada and Quebec}

Barbara E. Corbett (1989), author of A Century of Kindergarten Education in Ontario, traces the beginning of the Canadian kindergarten movement. She credits Egerton Ryerson, the Superintendent of Education for Ontario at the time, for preparing the province for Froebelian education. As editor of the Journal of Education, Ryerson published numerous articles on Froebel's kindergartens starting in 1872. Two Hours in a Kindergarten, written by Edward Taylor (1872), describes the amazement of the author 
after witnessing 62 young children dancing, drawing, and making models. Taylor's opinion was that kindergarten "was simply a supplement to natural processes" and gave the child "an awakened interest and an unfeigned devotion to mental pursuits" (p. 132). The Kindergarten in Canada, written in 1875 by an unknown author, spoke of the German kindergarten system's successes and the need for such a program in Canadian schools. The author eloquently concluded by stating:

If something could be done to supplement the present school system, excellent in many respects, by the addition of something similar to the kindergarten in Germany, that which is now a desert in our community in Canada might soon bloom as the rose. (p. 40).

According to the 1872 article Constructing Time Tables in Our Schools by James Hughes, ESQ (1872), class schedules in Canadian schools were unlike those in Germany as Canada's time tables were made to meet the needs of the teacher and not necessarily the needs of the students. Hughes, Master at the Boys' Model School of Toronto at the time, stated, "the more nearly a teacher can approximate the plan of having all his pupils engaged at the same work, at the same time, the more easy will be his labour, and the more rapid the advancement of his class" (p. 26).

In 1876, Hughes became the Inspector of Schools for Toronto. He visited the kindergarten display at the Centennial Exhibition in Philadelphia, which had been credited by Peabody and her fellow Bostonians. After numerous observations of kindergartens in the United States by Hughes and his team, the first public kindergarten opened in Toronto in January 1883. According to Corbett (1989), the school received wholehearted support from the people of Toronto while Hughes traveled giving public lectures on the topic. This, along with the many positive articles in the Journal of Education helped pave the way for kindergartens to open outside of metropolitan Toronto.

Quebec's kindergarten history is a fairly new one. In her chapter An Historical Overview of Child Care in Quebec, Ghislaine Desjardins (1992) provides readers with a thorough account of Quebec's childcare past and describes how its path led to the creation of the kindergarten. Desjardins writes that although there was childcare during the first half of the 19th century, due to the efforts of the Grey Nuns and various orphanages, many mothers placed their children in their care as a last resort. The French-speaking population used most of these shelters. The English community had only one day care center during the 19th century, The Montreal Day Nursery, which is still in existence today. These children's shelters were overcrowded and by the end of the 19th century many of their doors closed and they became orphanages. 
During the 20th century, Quebec society frowned upon working women, and held that no proper mother would allow another to raise and mind her child. Although there was sufficient demand for government-supported childcare, the Duplessis administration rejected the idea of assisting mothers working outside of the home. While various centers did exist, these shelters were privately owned, unsubsidized and often the care provided was not on par with social standards. Quebeckers were forced to wait for a government-supported kindergarten program. The Montpetit Commission (1933) stated the need for junior kindergartens, but it met with no success (Commission des assurances sociales de Québec, Ministère du Travail, 1933). On August 19, 1942, Prime Minister MacKenzie King highlighted the necessity for childcare in order to help with the war effort in his speech, Canada and the War: Manpower and a Total War Effort: "To help safeguard the welfare of the family, day nurseries for the care of children of working mothers are being established." In the 1950s, even after the baby boom and an influx of immigration, Quebec's daycares remained private. It was not until December 1979 that the Quebec government passed the Child Care Services Act, which outlined the government's agreement to play a role in the creation of childcare/daycare facilities (Éditeur officiel du Québec, 1979, chapter P-34.1). In total, 125 years passed before the Quebec government's view of childcare moved from being charitable, private facilities to being the responsibility of the government.

In II Était Deux Fois: L'Évolution De L'Éducation Préscolaire au Québec, Madeleine Baillargeon's (1989) places more focus on the Quebec kindergarten itself. Baillargeon states that the first kindergarten program was created in 1915, but little is said as to its curriculum or educational philosophies. Baillargeon writes in more detail of the kindergartens during the 1930s as some establishments were appearing across the province. The children in attendance, however, were those of the affluent who could afford private services. The first French public kindergarten opened only in 1950.

Poulin and Richard (2002) also describe the history of kindergarten in Quebec, but focus mainly on the present. According to them, by 1974 nearly $97 \%$ of Quebec's francophone children attended a kindergarten and by 1978, kindergarten was made more available to those with lower incomes, anglophones and allophones. During the 1970 s, the students attended on a half-day basis. The teachers of these classes were given much flexibility, because the official Quebec kindergarten curriculum was not written until 1981. Later, with the implementation of the full-day kindergarten in 1997, the government revised this curriculum. This program lasted only five years, and in 2001, following the new Quebec Education Reform, the government published Le programme de formation de l'école québécoise, which is still in use today. 
With the new education reform, a major shift was made in both the role of the teacher and the role of the students. Teachers were no longer seen as the only possible expert on a subject, but as guides to the students as they discovered their world (Ministère de l'Éducation, du Loisir et du Sport du Québec [MELS], 2001). The students were no longer taught by means of rote memorization or graded according to regurgitated facts. Instead, they were evaluated based on competencies, which, when mastered, could be applied for lifelong learning. This position of the active learner, searching for information, applying learned skills to new tasks, asking questions, and developing a global awareness are key factors to the 2001 reform. These philosophies of education and the philosophies of the MELS (Ministère de l'Éducation, du Loisir et du Sport) are similar to a constructivist approach to education, an approach based on the notions that learners construct their learning based on their environment, social interactions, and experiences.

The MELS' (2001) fourth chapter on preschool education outlines what can be expected in a Quebec kindergarten classroom as follows:

Activities are rooted in children's everyday lives and their human, physical and cultural environment. They give children the opportunity to discover various means of expression and creation and to become aware of the different languages that support and construct learning. (p. 52)

\section{Reflection: An Activity Rooted in Life}

After the school day had finished, a parent of one of my students approached me, asking for a quick meeting to speak about a pending situation in his home. This event would take "John" out of school for a prolonged period and alter his life as he knew it. The student in question had been adopted from China and his parents had their names on an adoption list for another baby. Their name had come to the top of the list and, any day, the family would leave together to meet and bring home a new baby. They did not know when they would receive the call, but when they did, everything in their lives had to stop and the adventure to China would begin. The parents were concerned not only for their son's education if he left for some time, but also for the disconnection he may experience being away from his peers and his daily routines. As a teacher, it was my wish to make this event a positive educational experience not only for John, but also for our classroom community as a whole.

As a group we conducted small research projects on China based on the questions provided by the students: Do they play hockey in China? What kind of food do they 
have? Is it cold there? This process allowed the students to take part in inquiry learning, thereby gathering insight into the culture of a classmate. Through our research, John became mentally prepared and excited for his upcoming trip.

The family received the call to go to Beijing and with that, John left our class for an undetermined amount of time. In order to keep John connected to his school and his friends, our inquiries into Chinese culture were taken a step further while the family was overseas. Through the magic of technology we conducted Skype meetings between John and our class. The task of proving our research findings through primary resources was put forth to John as he stayed in China. He therefore continued the inquiry process and would report his findings to the class through Skype.

As per the Quebec Curriculum, this lesson stemmed from the realities of the students. They were introduced to a new means of communication and their understanding of our world was enriched. The likes of Oberlin, Pestalozzi, and Froebel would have supported this endeavor, as the research did not move beyond the scope of the children because the inquiry was based on their reality. There was no memorization, but only true experiences where connections were made to their present situations, thus leading to genuine understanding.

Looking into the history of childhood and kindergarten education outlines the process that has paved the way for lessons, such as the student-led research described above.

\section{Kindergarten Today}

Today, Quebec's kindergarten program borrows from many of the philosophies previously outlined. This section will demonstrate how the philosophies of Dewey, Vygotsky, and Malaguzzi's Reggio Emilia enter the everyday curriculum.

Quebec's Kindergarten program respects Dewey's views of education, which he summarized in his 1897 Pedagogic Creed. He wrote that education should be child centered, and both action and interaction are necessary for deeper learning. The social world of the child and the community cannot be excluded from a student's education.

Teachers following the MELS program (2001) give students time for art and play, since "through their play and spontaneous activities, children express themselves, experiment, construct their learning, structure their thoughts and develop their worldview" (p. 52). The role of teacher as facilitator in the Quebec Education Program places 
high demands on teachers to create a stimulating learning environment where learners can take an active role in their learning. Teachers must produce resources fitting the children's inquiries and they must maintain and provide students with ample opportunities to apply their learning to various classroom and life situations. When teachers are successful in fulfilling these requirements, students become both active and interactive with their learning, thus following the constructivist view of John Dewey and Jean Piaget (1973a, 1973b).

The MELS program (2001) places a great deal of importance on observation because it "makes it possible to follow the children's progress in the development of their competencies" (p. 52). Quebec teachers are active participants in the students' learning and are seen as "mediators between students and knowledges" (p. 5). The program echoes Vygotsky's (1978) Zone of Proximal Development as the teacher's interactions with students should allow for the child to "carry out increasingly complex activities, stimulate their desire to surpass themselves and help them become aware of new realities" (p. 53).

The Quebec curriculum is also in line with Vygotsky's (1931/1997) notion of culturalhistorical development. Cultural-historical development theories state that, "through others, we become ourselves" (p. 105). Students enter the school environment with a multitude of diverse backgrounds. When teachers consider these contexts, and the students share their personal realities among peers, children become exposed to their world and in turn develop and reaffirm their identity. This idea of constructing one's identity is present in all subject areas taught in the Quebec curriculum. By exposing students to diversity, children learn to "affirm their choices and opinions, recognize their own values, accept differences and be open to diversity" (MELS, 2001, p. 32).

The Reggio Emilia approach, with child-centered activities focusing on relationships along with the child's ability to communicate through the 100 languages, has its place in the Quebec kindergarten program. The mandate for MELS program (2001) is for a child to develop an eagerness for school and to nurture curiosity and a personal drive for learning while preparing him/her both socially and cognitively for the years of schooling to come. Like Reggio, play and unprompted activity are encouraged during the school day, and through cross-curricular competencies, subject areas are not taught in isolation. The community is involved and interaction becomes paramount for learning.

The Quebec kindergarten curriculum, although child-centered and based on crosscurricular competencies, lacks the core values of a Reggio Emilia curriculum. As Sue Fraser mentioned to Carol Anne Wien in their 2000 interview, there is a lack of explicit insight into the multitude of relationships, their development and their importance in 
the kindergarten. The competencies outlined by the MELS, such as to affirm his/her personality, to perform sensorimotor actions, to complete an activity or project, to construct his/her understanding of the world, to communicate and to interact harmoniously with others (MELS, 2001) are, for the most part, focused on the development of the individual child - and not on the development of the child through the relationships created by interactions with peers, environment, community, and so forth. It takes a teacher who fosters a community of learners and values communication and empathy to implement Reggio values through the Quebec Education Program.

The Quebec Education Program for kindergarten, although encompassing the philosophies of Dewey, Piaget, Vygotsky, and, to some extent, Reggio Emilia, remains very broad, thus leaving much interpretation to the teacher to implement the curriculum. Future investigation into today's kindergarten classrooms and the curriculum realities implemented by Quebec's teachers would prove interesting research.

\section{Reflection: "Kid of the Day"}

In keeping with the Reggio idea of fostering and understanding relationships, and through interpreting MELS competencies of affirming personality, interacting harmoniously with others, and communication (MELS, 2001), I implemented "kid of the day" sessions at the end of each school day. This was one way for me to give the students personal satisfaction, confidence, and a sense of self-efficacy while developing group dynamics, empathy, and respect among students.

Appointed by the teacher, the "kid of the day" is a student who accomplished something special that day-overcoming a personal hardship, sharing, or helping a peer or simply starting the day with a smile. This child is singled out as the class sits together in a circle on the carpet. Once the teacher congratulates the student, it is left to the students to each take a turn in expressing one thing positive about the "kid of the day." It is understood that everyone has something good in him or her and we can all find that something. It is amazing to see the thought process and reflection as the students mature over time. At the start of the year many comments are superficial as they will mention how nice a child's hair, shoes or eyes are, but in time these comments become savvy. "I like how you played tag with me" or "I like how you helped me clean up the LEGO." They develop a heightened awareness of each other's good deeds and, of course, they all love being the "kid of the day" and hearing praise from their class community. These positive accolades breed positive relationships among the students. It allows students to contemplate their place in our class, their friendships and interactions. Founder of Reggio Emilia Malaguzi (1998) stated, "Children are not shaped by 
experience, but are the ones who give shape to it" (p. 86), and it is the students who drive this simple yet deeply powerful activity.

In learning of our past we can inform our present and better our future.

\section{References}

Airès, P. (1962). Centuries of childhood: A social history of family life. (R. Baldick (trans.). London: Penguin.

Baillargeon, M. (1989). Il était deux fois: l'évolution de l'éducation préscolaire au Québec. International Journal of Early Childhood, 21(1).

Brosterman, N. (1997). Inventing kindergarten. New York: Harry N. Abrams, Inc.

Corbett, B. (1989). A century of kindergarten education in Ontario. Toronto, ON: The Froebel Foundation.

Desjardins, G. (1992). An historical overview of child care in Quebec. In A. Pence (Ed.), Canadian child care in context: Perspectives from the provinces and territories. Ottawa: Statistics Canada and Health and Welfare Canada.

Dewey, J. (1897). My pedagogic creed. School Journal, 54, 77-80. Retrieved from http:// dewey.pragmatism.org/creed.htm

Edwards, C. Gandini, L., \& Forman, G. (Eds.). (1998). The hundred languages of children: The Reggio/Emilia approach - Advanced reflections. (2nd Ed.). Westport, CT: Ablex Publishing.

Fröbel, F. (1861). Die Pädagogik des Kindergartens, Gedanke Friedrich Froebel's über das Spiel und die Spielgegenstände des Kindes. Trans. Josephine Jarvis. 1909, New York: D. Appleton and Company. Eng. Title: Friedrich Froebel's Pedagogics of the Kindergarten, or, His Ideas Concerning The Play And Playthings Of The Child.
Gouvernement du Québec. (1979). Educational Childcare Act: Commission des droits de la personne et des droits de la jeunesse. (Publication No. chapter S-4.1.1). Quebec, QC: Canada, Printed by the Gouvernement du Québec. Retrieved from http://www2.publicationsdu quebec.gouv.qc.ca/dynamicSearch/tele charge.php?type $=2 \&$ file $=/$ S_4_1_1/S4_1_ 1_A.html.

Gutek, G. (1972). A history of the Western educational experience. New York: Random House.

Hughes, J. (1872). Constructing Time Tables in Our Schools. Journal of Education, Province of Ontario, 25(2), 25-26.

Kilpatrick, W.H. (1951). In his introduction to Heinrich Pestalozzi, The education of man Aphorisms. New York: Philosophical Library.

King, M. (1942). Canada and the War: Manpower and a Total War Effort. National selective service broadcast, Ontario. August 19, 1942. Retrieved from http://www.collectionscana da.gc.ca/primeministers/h4-4078-e.html

Ministère de l'Éducation, du Loisir et du Sport du Québec (MELS). (2001). The Quebec Education Program. Preschool and Elementary Education. (Publication No. 01-00611). Quebec, Bibliothèque Nationale du Québec.

Montpetit, É. (1933). Commission des assurances sociales de Québec. (Publication number 01-1439703) Ministère du Travail (Ed). Retrieved from http://ariane2.bibl.ulaval.ca/ ariane/?id=01-1439703

Morgan, H. (2011). Early childhood education: History, theory and practice. Plymouth, UK: Rowman \& Littlefield Publishers, Inc. 
Oberlin Museum. (n.d). www.musee-oberlin.com

Pestalozzi, J.H. (1894). How Gertrude teaches her children. Translated by Lucy E. Holland and Francis C. Turner, London: George Allen \& Unwin Ltd.

Piaget, J. (1973a). The child and reality. (A. Rosin, Trans.). New York: Grossman Publishers. (Original Work Published 1972).

Piaget, J. (1973b). To understand is to invent. (G. A. Roberts, Trans.). New York: Grossman Publishers. (Original Work Published 1948).

Plumb, J. H. (1971). The Great Change in Children. Horizon, 13(1).

Postman, N. (1981). The Day Our Children Disappear: Predictions of a Media Ecologist. The Phi Delta Kappan, 62(5), 382-386.

Poulin, G., \& Richard, N. (2002). La maternelle, un jeu d'enfants! Anjou, QC: CEC inc.

Rousseau, J. (1762). Émile. Trans. W. H. Payne. 1892. New York: D. Appleton.

Shapiro, M. (1983). Child's garden: The kindergarten movement from Froebel to Dewey. University Park: The Pennsylvania State University.
Silber, K. (1973). Pestalozzi: The man and his work. Wiltshire, UK: Redwood Press Ltd.

Taylor, E. (1872). Two Hours in a Kindergarten, Journal of Education for Ontario, XXV(9),132.

The Kindergarten in Canada. (1875). Journal of Education for Ontario, XXVIII(3), 39-40.

Vygotsky, L.S. (1978). Mind in society. M. Cole, V. John-Steiner, S. Scribner, \& E. Souberman (Eds.). Britton Cambridge, MA: Harvard University Press.

Vygotsky, L. S. (1931/1997). The collected works of L. S. Vygotsky. Vol. 4: The history of the development of higher mental functions. (W. Rieber, Vol. Ed., Marie J. Hall, Trans.). New York: Plenum Press (Chapters originally written or published between 1924 and 1934).

Wien, C. (2000). A Canadian Interpretation of Reggio Emilia: Fraser's Provocation. Canadian Children, 25(1), 20-27.

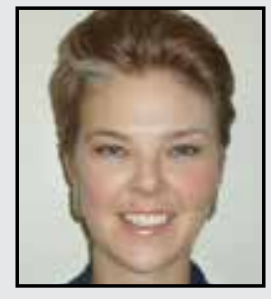

Lauren McCann is a full-time kindergarten teacher on maternity leave from Lower Canada College in Montreal and is also a Ph.D graduate from Concordia University's Art Education department. She is a firm believer in the countless capabilities of young children and continues to research their early literacy development and creative thinking through the arts. Lauren has presented at conferences in both North America and Europe and her articles have appeared in research journals and teachers' publications alike.

\section{LINK TO:}

http://www.lauren-mccann.com 